\title{
報文
}

\section{実験結核症に及ぼすクロレラ飼育の影響 \\ Effects of Feeding With Chlorella Gells on Experimental \\ Tuberculosis in Guinea Pigs}

(昭和 36 年 1 月 28 日受理)

羽 鳥 $\underset{\text { (Junko Hatori) }}{\text { 子 順 }}$

For the evaluation as a nutritious foodstuff of chlorella cells containing large amounts of protein and fat, guinea pigs were fed with the diet containing the freeze-dried cells of Chlorella pyrenoidosa in place of the bran in the common diet which also included bean-curd refuse and some vegetables, and the effects of feeding on the experimental tuberculosis were investigated.

The nutritious compositions of both diets were calculated and provided as follows: the caloric ratio of common diet, protein : fat : carbohydrate $=2: 1: 8$, total calorie, 168 cal. per day to each animal; the caloric ratio of ohlorella-diet, protein : fat : carbohydrate $=$ $1.4: 2: 1$, total calorie, 173 cal. per day to each.

After the feedings for 5 weeks with these diets, the animals were infected with $0.01 \mathrm{mg}$ of M. tuberculous $\mathrm{H}_{3 ;} \mathrm{Rv}$, and the feedings were continued for 5 weeks.

The autopsy was carried out at the sixth week after infection.

The results obtained might be briefly provided as follows:

1. It was recognized that the chlorella diet was quite useful for the animal feeding.

2. The skin reaction caused by tuberculin ( $\mathrm{xl} 00$ ) appeared at each third and fifth week after infection in both groups.

3. In the autopsy findings, the visceral lesions of the group fed with chlorella were less than those of the control.

4. The microscopic findings of lungs tended to be equal to the macroscopic visceral findings.

5. Colonies of tubercle bacilli developed less in the cultures of the spleen in the chlorella group than those of the control.

6. The absorption percentage of chlorella diet stood at $80 \%$.

第一次大戦中，西欧各国に於ける死亡率は一般に急昇 を示し，又結核の所見は，死亡率の高率並びに病勢の重 症化を示していた1)。

又我国住於ても，満洲事変勃発後昭和 8 年頃 (1931) より，結核死亡率は徐々に上昇を示し2)，第二次大戦中 の昭和18年 (1943) には, 参戦諸国と共にその頂点に達 した。これらは飢睋, 労傎過重, 一般衛生状態の低下が その原因といわれていた。従って戦後これらの国々で は，結核死亡率は順調に減少している。これら各国に於 ける結核死亡率が，戦争によりその影悲を受けている事 は, Lee $(1931)^{3)}$ Wolff $(1940)^{4)}$ その他の報告で明ら かな所である。
第二次大戦中及び戦後に欧州諸国で起った栄美失調が 同様に結核死亡率の上界に反映している事は，Daniel Marc $(1947)^{5)}$ Halls $(1948)^{6)}$ Hoef nagels $(1950)^{7)}$ 等 の報告によっても明らかである。第二次大戦の戦争末期 並びに敗戦直後我国に於ては, 国土の荒廃，且つ復員， 外地引場げ等による人口の増加は，我国の食糧事情の筑 そをもたらした。この時発生した栄養失調症の結核疾患 に対する影響は, 病理解剖学者等によっても明らかにせ られている899101。

その後輸入食䊓により，次第に我国の食糧事情も好転 し,これに加うるに, 各種の結核化学療法及び, 胸部外 科療法の発達は, 結核治療につけて, 栄美療法の関心を 
少なからしめて今日に至っている。

しかし御園生 (1955) ${ }^{11)}$ は, 海外各国の結核死亡率と 食慨との関係を注目し，次の梯に述べている。その1951 年から1952年における期間の調査によれば，国民 1 人当 り1日に掑取し得るカロリーが，大体3000カロリ一以上 の国では，結核死亡湾汸何れも低く，10万对20以下とな っており，2500カロリ一以下の国では大体10万対50以上 の高死亡率を示している。

又動物性食品の占める高も20\%以下の国では，結核死 亡率涂り低くないと述心，更に我国における搨取力口 リーの低い事，特に動物性食品の拱取量の少ない点を指 摘して、これが我国に結核の多い原因の一つにあげてい る。又昭和28年, 広沢, 原 $\left.{ }^{12}\right)$ は, その栄養調査より我国 成人の攝取カロリーが少なく，蛋白特に脂肪掞取の低い 事を指摘した。

その結果は, 赤血球数の減少, 血獎蛋白澌の低下等, 医学的検查の成綪にも影著に現われている事を述べてい る。かかる生活水隼の低、生活が知病，特に結核に対す る抵抗性索弱内，その恢復点遅的せている事は，Rich (1951) $)^{13)}$ の文献にも述心られているように, 欧洲に於て も明らかにせられていることである。

結核症の感染発病考考える時, 個体の持つ先天的抵抗

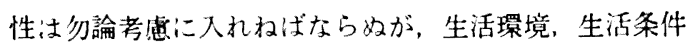
（労㗢条件，栄条件）が持つ役割も亦等閑視す心゙きも のではないと考える。

Goldberg $(1947)^{111}$ によ玌ば，結核症に於て注，組織 蛋白質の崩壊、消耗があ门, 破壊組織修復のため, 蛋白 質は特に重要な養素であると述べている。

当所附属㙩養所に於汁る患者食祖沉ついてみるに，昭 和23年 5 月，即ち給食老始めた頃は、総力ロリー2,000 蛋白質約 $70 \mathrm{~g}$, 脂肪 $10 \mathrm{~g}$, 炭水化物 $410 \mathrm{~g}$ であった。従 ってこの三荃素のカロリーの比は， $3: 1: 18$ でった。 併し此等の量注次第に改善され，総力ロリー2,500, 蛋白 質約 $90 \mathrm{~g}$, 脂肪約 $47 \mathrm{~g}$ となり以後大体此の線を維持して 今日に至っている。最近 3 力月間 (35年7.8.9 月) に於 ける当所附属療養所患者食の蛋白澌, 脂肪, 炭水化物の 平均カロリ一の比を調べてみると, 脂肪を 1 とすると, 蛋白質は 0.8 , 炭水化物 3.2 で, カロリ一比は $0.8: 1: 3.2$ の数值を示した。

食䁒の結核症に及ぼす影響の研究についてみると，先 す Weigert (1907) ${ }^{153}$ は脂肪有糼説を称えた。彼流高脂 肪食を与えた豚に牛型結核菌を接種した所, 高炭水化物 を与えた群より発病したものが少ないと報告している。

我国汸於ても，昭和 7 年熊谷 $(1932)^{16)}$ は，日本の結 核発病及び羅患数の多、原因の一つは，国民食詯中の低 脂肪量にありとし，脂肪豊蜜食を推奖した。更に第二次

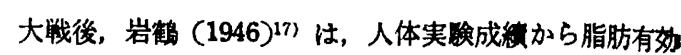
説を強調している。次に蛋白梊有効説を主强したもの に, Thomas (1913) ${ }^{18)}$ Hornemann (1913) ${ }^{19}$ 長浜 $(1927)^{20)}$ Kerner, Getz 及び Long (1949)21) 等があ る。Thomas ${ }^{18)}$ 及び Hornemann ${ }^{19)}$ は豚を用いて実稀 し, 高蛋白食郋群は, 高炭水化物食秱群に比して病変が 軽く，結核症の進展阻止に好影響を与える。併し高脂肪 食郋群では，その成綪は不定であると報告した。

又 Kerner, Getz, Long ${ }^{21)}$ 等は，大黒鼠を用いて実 験を行ない，高蛋白質群は，病巣中の結核菌数が少なく 治瘾の傾向を認め，低蛋白質群では，菌数も多く，病紧

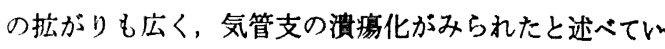
る。長浜 ${ }^{20}$ は，ラッテ及びマウスに人型結核菌を感染さ せ，これらに牛肉を主とする高蛋白食飼育と立米を主と する高炭水化物飼育を行ない，その経過に及ぼす影签を みた。その結果, 牛肉主食に於ては病変は一般に軽く, 增殖型が多いのに反し，玄米主食のものは，急性湢出性 で，破壊性に富み，高蛋白群に比較して重症であったと 報告している。

又難波 $(1934)^{22)}$ も結核感染ラッテを夫々蛋白澌及び $\mathrm{Ca}$ 主食, 脂肪主食, 炭水化物主食に分けてこれを飼育 し，結核の進行に及ぼす影響を調くた。結論として結核 江对寸る食饵は，炭水化物上り蛋白質乃至脂肪或いは， Ca に富む食铒を供給する方がよいと述べている。

Ratcliff $(1946)^{23)}$ は動物園の鳥類に対して，穀物の みによる食触を，蛋白啠の質と量を改良した混合食慨を 与える事により，鳥型結核症の頻度を著明に減少させた と報告した。

Dubos (1955) 24) はマウスの食䁒について，結核症に 対する抵抗性を調へた結果，低蛋白啠炭水化物飼料は， 感受性を亢め, 低蛋白質高脂肪飼料は, その抵抗性注正 常であったと報してている。以上述べたごとく，従来結核 に対しては, 或いは高脂肪食期の有効性が説かれ, 或、 は高蛋白質食期が推奖されたが，中村 $\left.{ }^{25}\right)$ は, 肺結核に対 する高脂肪食の意義は，高蛋白と高脂肪にあるといい， 至適三養素配合比という事に重点をおいて研究を行なっ た。

即ち中村隆 $(1955)^{25)}$ は，無機物質並びに，ビタミン 類を含ませ, 蛋白質, 脂肪, 炭水化物の三大栄美素の比 染を種々に変えて, マウス並びに人体の結核症に及ぼす 影響をみた。その結果は, 高蛋白食は, 白鼠の成長並び に結核感染経過に良好である。更にこの際, 適当の脂肪 を增加する事によって，より効果を期待し得るものであ るとして, 結模症に対する高蛋白高脂肪食聑を強調し た。

又柳 $(1952)^{26)}$ は良澌なる栄荃, 更にピタミン類の十 
分なる補給が，結核症の䍜患率を低めると述へ，小川 (1952)27) も，結核患者の栄垬については，健康人の食 聑よりも蛋白所，殊に脂肪を多量に与える事が望ましい と述べている。次に化学療法と食眲の関係についてみる と, 鈴木 $(1959)^{28)}$ は，低蛋白低脂肪，低蛋白高脂肪， 高蛋白低脂肪，高蛋白高脂肪，固型飼料の 5 種の飼育方 法で，結校感染マウス及び，非感染マウスを飼育し，そ の発育状態を镜察した。

更に結核感染マウスに Streptomycin (S.M.), Isonicotinylhydrazine (INH) を使用し,その効果と, 栄養との関係をみた。一方 INH 大量投与時における中 毒現象を栄荃的観点から検討した。その結果，非感染? ウス及び感染マウスの低蛋白質群の死亡率は, 高蛋白質 群の死亡率上り圧倒的に多く, 又感染マウスに化学㙩法 を加えた時，INH を投与した場合，体重の推移につい ては，低蛋白質群より高蛋白質群の方が好成績であった。 尚低蛋白高脂肪はむしろ悪い結果を来たした，又 INH 大量投与による INH の毒性 (死亡率) は高蛋白質群に 低いと述べている。この事は，蛋白質が薬㓮の解毒作 用に重大な役割を示していると考えられる。又杉山 (195729) は, 血中ケト酸增加上, 結核菌の增殖上の関 伱から, 病状の進展に伴い, 血中ヶトン体の上昇妾みる 例が多く，この様な患者に脂肪を負荷する事は, 代謝障 害ある炭水化物を強いて然焼させる結果となり，望まし い事でないといっている。

著者は，モルモットを用いて，クロレラを飼料として 飼育実験を試み，更に実験結核症への影䈉を調べた。対 照として当結核研究所飼育法 (以下結研飼育法と略寸) による動物群を用いた。

クロレラは光合成によって淡水に增殖する単細胞生物 であって，Warburg (1919)30) の研究によれば, 蛋白 澌, 脂肪の含量が他の植物に比して多く, 又カロリーの 豊富な植物であると報告せられている。又Spoehr $(1947)^{311}$ は, 各国にクロレラの研究を提唱し, 田宮

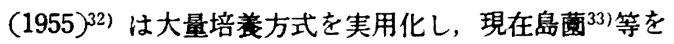
中心としてこの栄美学的検討が行なわれつつある。馬場 (1958，1959)3）等は，蛋白分の抽出精製を研究してい る。又クロレラの食物利用に関する報告は，動物飼料と して, Geohegen (1953) ${ }^{35)}$ Fink (1957) ${ }^{36)}$ 等によるラ ッテ飼育実験, 中村 $\left.(1958)^{37}\right)$ のラッテを用いた栄養試 駼並びに，荒川 $(1958)^{38)}$ 等の鷄飼育実験があり，何れ もその栄養価は大豆に比へて勝るとも劣らぬものであ り，動物飼育上何等の障害又は副作用は認めなかったと 述へてている。更にマウスを用いて荒川 (1959)39) 等は, 饲育実験を試み、クロレラの栄養価を成長及び病原性に 対する抵抗の点から検郡した。
その結果，クロレラを含む飼料は，マウス飼料として 使用し得られ且つ，駒込 B III赤淑菌に対する抵抗力が強 い事を報告している。

しかるに正常モルモット及び結核モルモットについて 今迄クロレラによる飼育実験は陚みられていない。従っ て以下これを行ない，成績について報告する。

\section{実験材料と方法}

動物は体重 $350 \mathrm{~g}$ 前後の雄モルモットで何れも 100 倍 ツベルクリン (「ツ」と略す) 反応陰性のもの 10 匹を用 い,これをその飼育方法により 2 群に分け，各々 5 匹宛 としたっこれをクロレラ実験群 (「ク実験群と略す) 対 照群とし, 室温 $15^{\circ} \mathrm{C}$ 前後で飼育した,

「ク」実験群飼料中に含まれるラクロレは，財団法人日 本食生活協会, 国立クロレラ研究所上り分与された新鮮 クロレラの凍結乾燥したものを用いだ。

凍結乾燥条件 400 は, 箱型乾燥器考用いて凍結温度 $-20^{\circ} \mathrm{C}-25^{\circ} \mathrm{C}$ で 2 時間凍結した，その後 $-10^{2} \mathrm{~mm}$ $\mathrm{Hg}$ の真空となし, 乾燥時間を早めるため, $+30^{\circ} \mathrm{C}$ 迄 徐々に加温して減圧乾燥した。

飼料の配合量及び 3 養素配合比法，第 1 表に示寸如く である。尚ビタミン，ミネラル攝取量について食品分析 表より「ク」実験群は，対照群に勝るとも劣る事はなか った。

第 1 表 1 日 1 匹当りり飼料分析表

\begin{tabular}{|c|c|c|c|c|c|c|}
\hline \multirow{2}{*}{ 群 } & \multirow{2}{*}{ 品 } & \multirow{2}{*}{$\begin{array}{c}\text { 量 } \\
\mathrm{g}\end{array}$} & \multirow{2}{*}{ Cal } & 蛋白質脂 & \multicolumn{2}{|c|}{ 肪宸水化物 } \\
\hline & & & & $\mathrm{P} \quad \mathrm{g}$ & $\mathrm{g} \mathrm{Ch}$ & $\mathrm{g}$ \\
\hline & キャベッ & 45.00 & 10.35 & 0.64 & 0.13 & 1.58 \\
\hline 実 & オカラ & 37.50 & 25.13 & 1.65 & 0.80 & 2.62 \\
\hline 臨 & クロレラ & 25.00 & 137.50 & 11.25 & 7.50 & 5.00 \\
\hline \multirow[t]{2}{*}{ 群 } & 合 & 計 & 172.98 & 13.54 & 8.43 & 9.20 \\
\hline & \multicolumn{6}{|c|}{$\mathrm{F}: \mathrm{Ch} \mathrm{Cal}$ 比 $1.4: 2$} \\
\hline & キャペツ & 65.00 & 14.95 & 0.93 & 0.17 & 2.28 \\
\hline 対 & オカ & 37.50 & 25.13 & 1.65 & 0.80 & 2.62 \\
\hline 照 & $7 \pi \checkmark$ & 40.00 & 128.00 & 5.63 & 0.63 & 24.00 \\
\hline 群 & 台 & 計 & 168.08 & 8.21 & 1.60 & 29.00 \\
\hline & & $\mathrm{F}: \mathrm{Ch}$ & Cal 比 & $2: 1$ & $1: 8$ & \\
\hline
\end{tabular}

但し,クロレラは P 45\% F 30\% Ch 20\%として 計算した。

実験を実施するに当っては，始めにモルモット10匹を 全部一応結研飼育法で数日間飼育を行ない，その後実験 群に固有の実験食による飼育を行なった。

対照群飼料は, 結研飼育法によるもので, 野菜, オ力 ラ, 蛋白犋, 脂肪, 炭水化物のカロリー比は 
$2: 1: 8$,「ク」実験群飼料は, 野菜, オカラ, クロレラで 3 崣素のカロリー比は， $1.4: 2: 1$ である。これら両群 を 5 週間飼育した後, 第 6 週目に雨群に $\mathrm{H}_{37} \mathrm{Rv} 0.01 \mathrm{mg} /$ $0.5 \mathrm{cc}$ を皮下接種し，更にその後 5 週間続けて観察を行 なった、そして感染後 6 週始めに屠殺解剖して所見を観 察した

\section{観察方法は}

1）体重の測定：各群飼育開始時上り菌接種前後を通 じ，毎週一回，朝の飼料投与前に全動物の体重を測定し た。

2)「ツ」反応測定 4142$)$ : 菌接種值前, 接種後 3 週及 び 5 週目に 100 倍「ツ」皮内皮応を行なった。

3) 剖娭：結㮎菌接種後 6 週目にこれ在行なっだ。剖 検時汇内臟所見の肉眼的䧽察を行ならと其に，脾の重最 測定を行なった。

4) 組織学的所見: 肺, 肝, 椫及び気管支淋已腺につ い一，人マトキシリン，エオジン染色及び鋃銀染色を行 なって組織学的所見を観察した。

5) 臟器定量培養: 肺, 椫の結核菌定量培荃を小 川(3)の方法に準拠して行なった。

6) 投与されたクロレラ飼料の実呀動物体内吸収量に つルて、クロレラに含まれるクロロフィル叟を抽出測定 し，また健康亚びクロレラ飼育モルモットの粪中のク ロロフィル量を測定した。これらを用いて吸収量を\%を 以って現した・クロロフィル昏の測定方法は乾燥クロレ ラ，クロレラ飼㕕モルモットの秶並びに健康モルモット （結研飼育法による）の倛の $4 \mathrm{~g}$ を科量しこれよりクロ ロフィルをメタノール100ccにて、ソックスレー装置を 用いて抽出した。抽出時間は61時間とした。この抽出液 中のクロロフィル量測定にはクロロフィリン $1 \mathrm{mg}$ をメ タノール100cc に浴解した液を標隻基準液として用い た，尚日立製分光光度㝄を用いて比色定量した。(条件：
測定波曼 $407 \mathrm{~m} \mu \mathrm{pH} 4.5$ )

\section{実 験 成 績}

1) 体重の変化

第 1 図に示すごとく，哴育開始時の平均体重仙両群は ほ等しく，飼育後 2 週目より，共に增加を示した。第 6 週目に両群に $\mathrm{H}_{37} \mathrm{Rv} 0.01 \mathrm{mg} / 0.5 \mathrm{cc}$ を注射し, 更に镜塞 を続けた。その後も僅か乍らも「ク」実稌群の方が上位 を示して，両群の差は略々平行線をたどった。

2）「ツ」皮内反応の変動

感染直前 全動物は「ツ」陰性であった。感染後 3 週 及び 5 週の 100 倍「ツ」皮内反応は両群共に晹性を示し， 且つ第 2 表に示すごとく，両群共，その硬結径の平均恃 ほほ同椂の值を示した。

第 2 表 100 倍「ツ」皮内反応の変化（硬結径）

\begin{tabular}{|c|c|c|c|c|c|c|c|}
\hline \multirow{3}{*}{$\begin{array}{l}\text { 群 } \\
\text { 対 }\end{array}$} & \multirow{2}{*}{$\begin{array}{l}\text { 番 号 } \\
2 \\
2\end{array}$} & \multicolumn{3}{|c|}{ 菌接種後 3 週 } & \multicolumn{3}{|c|}{ 菌接種後 5 虺 } \\
\hline & & \multicolumn{3}{|c|}{$12 \mathrm{~mm} \times 11 \mathrm{~mm}$} & \multirow{2}{*}{\multicolumn{3}{|c|}{$\frac{-}{9 \mathrm{~mm} \times 13_{\mathrm{mm}}}$}} \\
\hline & 3 & 11 & $x$ & 16 & & & \\
\hline \multirow{2}{*}{ 照 } & 4 & 12 & $x$ & 15 & 16 & $x$ & 24 \\
\hline & 5 & 13 & $x$ & 13 & 11 & $x$ & 14 \\
\hline 群 & 平均 & 12 & & 13.7 & 11.6 & $x$ & 17 \\
\hline \multirow{5}{*}{$\begin{array}{l}\text { 英 } \\
\text { 踰 } \\
\text { 群 }\end{array}$} & 2 & 13 & $x$ & 12 & 6 & $x$ & 9 \\
\hline & 3 & 14 & $x$ & 17 & 12 & $x$ & 16 \\
\hline & 4 & 6 & $x$ & 7 & 13 & $x$ & 16 \\
\hline & 5 & 14 & & 18 & 14 & $x$ & 17 \\
\hline & 平均 & 11.8 & $\times$ & 13.5 & 11.7 & $\lambda$ & 14.3 \\
\hline
\end{tabular}

3）肉眼的解剖所見

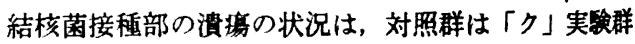

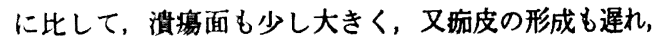

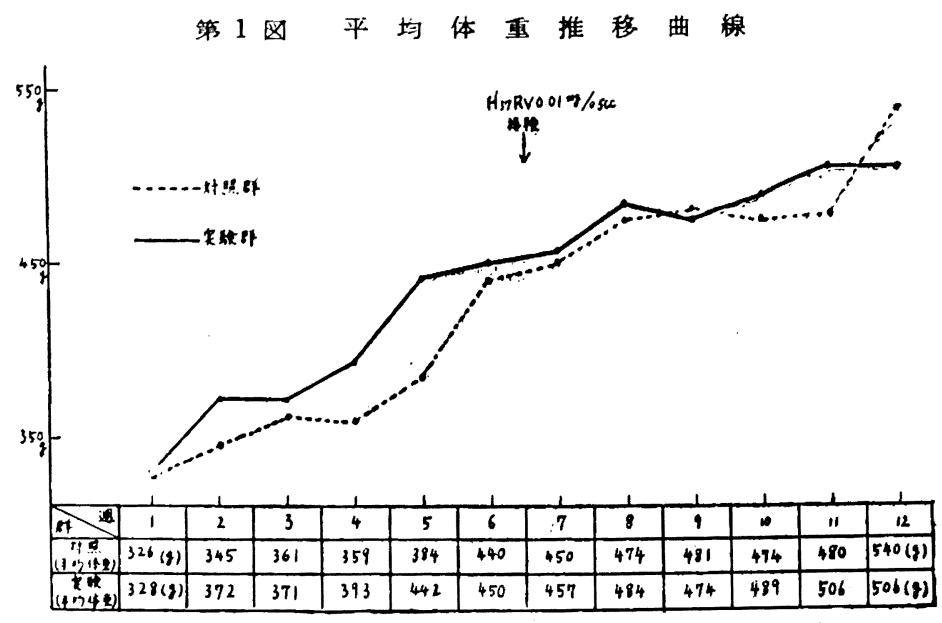

( 166 ) 
第3 表䑏器及び淋巴腺の肉眼的所見

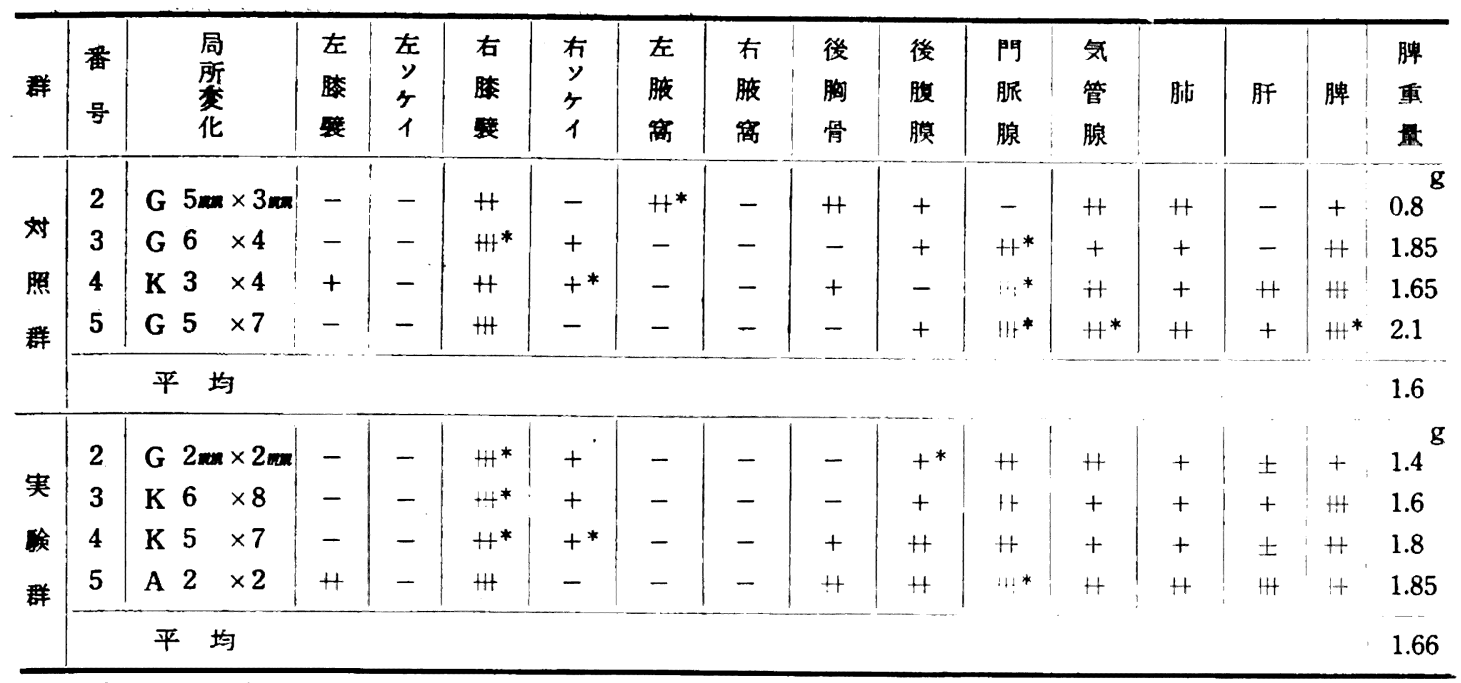

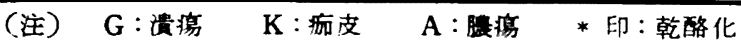

治套の傾向が遅れがちであった，又腀器及び淋巴腺の結 核性変化は，第 3 表に示すごとく、画群に大差を認めな かったが, 平均して满器病変は「ク」実験群の方が, 対 照群に比して僅か乍ら軽度であった。

両群の嗒器及び淋巴腺病変のヒストグラムは, 第 2 図 に示すごとくである。脾の平均重量は「ク」実験群 $1.6 \mathrm{~g}$ で，対照群は $1.66 \mathrm{~g}$ であった。

第2因ヒストグラム
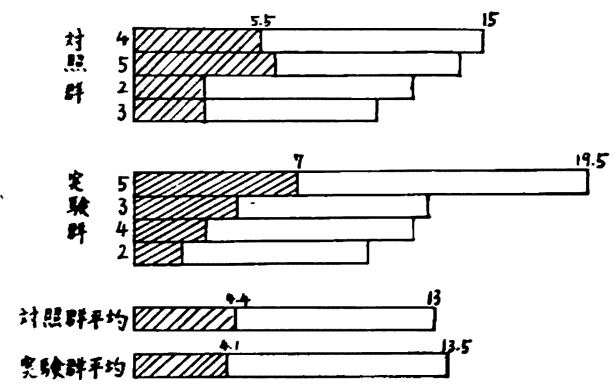

4) 死亡数

対照群では， 6 週目に 1 匹，剖検直前に 1 匹計 2 匹， 「ク」実験群ではクロレラ飼育開始後 5 週目に 1 匹の死 しをみた。

5) 組織学的所見

肺：「ク」実験群は対照群より変化が軽く, 肺胞壁浸 閗の形を主体とするも，末だ結節形成は認められず，対 照群は一般に血管周曲の細胞浸洞及び肺胞壁の細胞浸洞 がビマン性に軽度にみられた。繁殖性類上皮細胞結核結 節が処々に散在してみられた。
肝：「ク|実験群，对照群共にほぼ同様の所見を呈し た, 即ち肝細胞は, 何れもほぼ正常, 各標本を通し， 1 乃至数個の類上皮細胞結核結節が撒布し，一部格子繊維 の増生の起り始めたものもみられ, 膠原化及び壊死はほ とんど認められなかった。

脾：対照群は大体に於て，原形質の広い，核の丸い類 上皮細胞の結核結節からなり，格子繊維がかなり增生さ れ，結核結節の融合傾向は少なく，壊死は認められず， 「ク」実験群に於てもほぼ同様の所見を呈した。

気管支淋巴腺「ク」実験群，対照群共にほとんど大差 は認められなかった，両者共格子㵶維形成の比較的盛ん な増殖性結核結節が多数散在し，多くは融合性上壊死も かなりの籁讲にみられた。

6) 腀器内結核菌定星培善成績

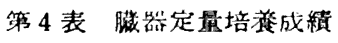

\begin{tabular}{|c|c|c|c|}
\hline 群 & 番 号 & 战 & 脾 \\
\hline \multirow{2}{*}{ 対 } & 3 & 0 & 255.0 \\
\hline & 4 & 0.2 & 1343 \\
\hline 照 & 5 & 0 & 430.0 \\
\hline 群 & 平均 & 0.1 & 273.1 \\
\hline \multirow{4}{*}{ 酸 } & 2 & 20.5 & 44.7 \\
\hline & 3 & 0.1 & 71.7 \\
\hline & 4 & 0 & 140.0 \\
\hline & 5 & 4.7 & 6.0 \\
\hline 群 & 平均 & 6.3 & 65.6 \\
\hline
\end{tabular}


肺, 脾の㖶器定量培荃所見は, 第 4 表に示すごとくで 肺に於ては「ク」実験群の平均コロニー数は 6.3 個, 対 照群は 0.1 個, 脾においては「ク」実験群では平均 65.6 個で, 対照群 273.1 個に対して約 $1 / 4$ のコロニー数であ った。

7）クロレラ体内吸収率測定成績

第 5 表に示すごとく，4g の乾燥クロレラ，クロレラ 食結核モルモット糞, 結研式飼育モルモット糞のクロ ロフィル量は、それそれれ $182.46 \mathrm{mg} / \mathrm{dl}, 91.29 \mathrm{mg} / \mathrm{dl}$,

$1.83 \mathrm{mg} / \mathrm{dl}$ であった。クロレラの1日摇取量 $25 \mathrm{~g}$ ，また 1 日平均排粪量約 $10 \mathrm{~g} て ゙$, 従って 1 日量のクロレラ含有

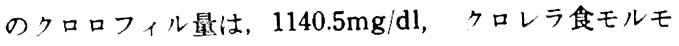
ット糞並に結研式飼青による健康モルモット蕒はそれぞ れ $228.2 \mathrm{mg} / \mathrm{dl}, 4.6 \mathrm{mg} \mathrm{dl}$ であった。従って体内クロレ ラ吸収率は $\frac{1140.5-(228.2-4.6)}{1140.5}=$ 約 $80.4 \%$ 。であった。

第 5 表クロロフィル抽出策

\begin{tabular}{|c|c|c|c|}
\hline 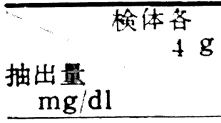 & 乾ロレラ & $\begin{array}{l}\text { クロレラ食 } \\
\text { 結核モルモ } \\
\text { ッ㟟 }\end{array}$ & $\begin{array}{l}\text { 結研式 食 } \\
\text { 僻康モルモ } \\
\text { ッ䣏 }\end{array}$ \\
\hline クロロフィル量 & 182.46 & 91.29 & 1.83 \\
\hline 量 & 1140.5 & 228.2 & 4.6 \\
\hline
\end{tabular}

\section{総括及び考察}

肺結核症の食諵療法としては，ギリシャ時代にさかの ほってみる事が出来る。即ち, Hippocrates (B.C460 $370)^{44)}$ が, 肺病患者の治療法として, 転地療法, 消化し 易い食物，牛乳療法を推奖していた。次でローマ時代, Cornolius, Celsus (B.C 43, A.D 20) Arethaeus ( 2 世 紀頃) Galenus (130２01）等も牛乳療法をす寸めた。 それ以来, 時代によって考え方に多少の相違はあっても 結核患者に対する食餉療法は，安静，大気療法と共に結 核治療の三大基本の一つをなしている(5)。結核動物の栄 美関して，中村 $(1952)^{25)}$ 洨，三大栄養秦の比率在種 々に変えて, 白鼠の成長並びに結核感染経過に及ほす影 掣を調べてこれを報告した。その結果, 飼料中の脂肪量 の影響は，蛋白質量により，極めて大きく左右される。 又白鼠の成長並びに結核感染経過に至適な蛋白含量は, 脂肪並びに炭水化物の相互関係により規制せられると述 へている。Dubos (1955)24) も, 生後29日か532日の白 鼠に結核菌を接種し，蛋白質と脂肪含量を変化させた食 郋を与えて, 結核菌に対する抵抗性の変化を調べた。結 果は, 低蛋白高炭水化物飼料は結核の感受性を六める。 併し，炭水化物を脂肪に固換した場合には，抵抗性は正 常であった。従って抵抗性の減少は，（1）体内に貯满さ
れるグリコーゲンの消耗，(2) 炎症細胞の解䊀作用の诚 弱，(3) 組織内にある Polycarboxylic acid やケトンの 増加等，代即筧乱によるものであるといら仮説を述べて いる。又中村 ${ }^{25)}$ は，結核患者の食餌実跧の結果，次の絑 に述べている。

（1）炭水化物は病单一般に渗出型に傾き，重症例では 腸結核，結核性腹膜炎を併発し易いので結核食としては 不適当である。（2）動物性蛋白質を十分にし，且つ脂肪 を多くしたものは，喀血を激減し，病宩は一般に硬化性 に傾き易いので，結核食として良好である。併し比較的 低蛋白食㑑に，高脂肪を与えたものは，炭水化物を与え たものより悪くはないが，余り良い成續を示さなかっ た。

柳 $(1952)^{26)}$ ，小川 $(1952)^{27)}$ も同様に述へてている。著 者はここに高蛋白，高脂肪を含有するクロレラを飼料と して，実験結核症への影郎を結研飼育法による動物群を 対照として，奏験した。その結果は，

(1) 平均体重の変化は，両群共に大差なく，稍々「ク」 実験群に增加を認めた。

（2）菌接種後， 3 週及び 5 週目の 100 倍「ツ」皮内反 応は，共に陽性を示し，且つ両群共その硬結径の平均は 略々同様の值を示した。

(3)肉眼的解剖所見は, 内满病変は「ク」実験群に稍々 病変の軽度を示したが,一方淋巴腺病変は両群に差異を 認めなかった。

(4) 組織学的所見は, 肺に於ては「ク」実験群の変化が 対照群に比してやや㹩度であったが，肝，䛲，気管支淋 比腺の変化は，両群に殆んど大差は認められなかった。

(5) 肺，脾の結核菌定量培養所見の平均は，肺に㧤い て対照群 0.1 個に対し「ク」実験群 6.3 個，脾において は, 対照群 273.1 個に対し，「ク」実験群 65.6 個で約 $1 / 4$ の集落数を示した。

(6) 実験動物のクロレラ体内吸収量は, 前記の方法に より，その吸収率は， $80.4 \%$ であった。

前記の成績は，正常モルモットに対して，クロレラは 慗に代用されるものと考えられる。

結核モルモットに対して，対照群より稍々良好なる成 績を示した原因として，(i) 高蛋白高脂肪にのみよるも のか。 (ii)「ク」実験群におけるクロロフィルの投与の 多少によるものか。 (iii) クロレラ Vitamin A 以外の 細菌性疾患に抵抗性を附与する物犋の存在によるか。今 後の研究にまたねばならぬ。因にクロロフィルの結核菌 に対してその発育阻止のある事は，Bowers (1947) の文献その他並びに最近当研究所に於てクロロフィル水 銀の結核菌阻止作用を工藤47)が認めている。 


\section{結論}

高蛋白，高脂肪を含有する淡水産単細胞緑藻クロレラ を飼料として，モルモットを飼育した。更に実軻結核症

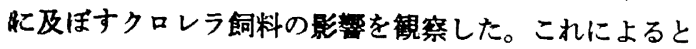

1）クロレラ飼育群は, 対照群に比して, 体重の変化 飞於て差異を認めなかった。従ってクロレラは，モルモ ットの飼料として，代用し得るものと考えられる。

2）結核病変に及ぼす影製は

（i）肉眼的解剖所見に於ては, 対照群に比して僅か乍 ら病変の怪度を示した。

(ii) 組織学的所見に於ては, 肺に於て「ク」実験群は 対照群よりその変化は㹩度であった。

3）細菌の集落数は, 肺は於て対照群より多く, 脾に 於ては「ク」実験群は対照群より少なかった。これらの 原因については更に検討中である。

稿を終るにあたり，終始御想篤なる御指導と御鞭撻を 賜った湯沢所長, 御校閲を賜った岩崎研究部長, 大林副 部長, 御援助を賜った続木科長, 岩井科長, 松崎, 青 木, 工藤（贤治）の諸先生並びに終始御協力賜った内山 氏，松沢氏に心から感謝致します。

尚クロレラを御恵与下さった南クロレラ研究所長に篤 く感謝致します。

\section{文献}

1) Redeker: Hand. d. Tbc. 468 (1958)

2）岛 尾：結核交龫抄録速報 778 (1959)

3) Lee, W. W. : Am. Rev. Tbc, 24, 326 (1931)

4) Wolff G.: Am. Rev. Tbc. 42, 214 (1940)

5) Daniel Marc: Tubercle, 28, 233 (1947)

6) Halls: Tubercle, 29, 21 (1948)

7) Hoefnagels: Tubercle 31, 198 (1950)

8) 岩 绮: 未発表 (1945)

9) 上田, 中西：猃断と治类，23，39 (1948)

10）鈴江，天野：日結， 7, 365 (1948)

11) 御園生: 結核文献抄録速報料上展望6, 382 (1955)

12）広沢，原，中山：潜生 No. $287: 15$ (1951)

No. $291: 2$ (1952)

No. 296: 2 (1952)

13) Rich: 結核病理発生論上(隈部訳) 463 (1951)

14) Goldberg: Clinical Tbc. C 43 (1947)

15) Weigert: Berl. Klin. Wochsch. 44, 1209 (1907)
16）熊谷：日本内科学会倠誌，20，47 (1932)

17) 岩隹：結核，23，1 (1948)

18) Thomas: Bioch. Zeit., 57, 456 (1913)

19) Hornemann: Bioch, Zeit. 57, 473 (1913)

20) 長棌：大阪大医学雑誌，26, 353 (1927)

21) Kerner, Getz, Long: Proc. Soc. Exp. Biol Med. 71, 154 (1949)

22）難波：日本内科学会雑誌，22，24(1934)

23) Ratcliff : Am. Rev. Tbc., 54, 389 (1946)

24) Dubos: Jour. of Exp. Med., 101, 59(1955)

25) 中村：日結, 11, 142 (1952) 結核石究の進步，9，19（1955）

26）柳：日結, 11，137(1952)

27) 小川：日結, 11, 149 (1952)

28）鈴木：医療，13，632. 694.811 (1959)

29）杉山：䑑床上研究，34, 1225 (1957)

30) Warburg: Biochem. Zeit. 100, 230 (1919)

31) Spoehr, Milner: Carnegie Inst. of Washington Year Book, 47, 100 (1947)

32）田宮: The Proceeding of the World Sym. posium on Applied Solar Energy, Phoenix 231. Arizona. (1955)

33）島薄：昭和 31 年度厚生科学䂙究補助金に上る 食生活改善に関寸る研究「必須厂ミノ酸源利 用」(1957)

34）馬場:「研究報告」国立举漛研究所, 10(1958) " " 7(1959)

35) Geohegen : Algal Cultur from Lab. to Pilot Plant, edited by Johus. Burlew, 182 (1953)

36) Fink: Conference on Solar Energy, the Scientific Basis at the University of Arizona, Tucson (1955)

Fink, Herold: Hoppe-Seyler's Ztschr. f. Physiolog. Chemie 305 (1956)

$$
\text { " } 307 \text { (1957) }
$$

37）中村：「必須アミノ酸盗源の利用に閣する研 究」研究報告, 昭和 32 年度厚生科学研究補助金 による食生活改善に関する研究，15(1958)

38）荒川：総合医学, 15, 173 (1958)

39）荒川：総合医学，16,965 (1959)

40）中村一男：真空技術と凍結乾燥 (1954)

41) P. Römer: Beit. z. Klin. d. Tbc.

11, 79 (1908)

14, 1 (1909)

42) Lewis, Aronson: Am. Rev. Tbc.

7, 404 (1923)

43) 小川(辰): 結核, 24, 19 (1949)

44) 岡西: 日本結核全書, 1, 1 (1957)

45）岡西：肺結核治療の变要 (1948)

46) Bowers, W. F. : Am. J. of Surgery, 37, 37 (1947)

47）工藤：末発表

（結核子防会 結核研究所） 